Environmental Research Journal 13 (1-4): 1-20, 2019

ISSN: $1994-5396$

(C) Medwell Journals, 2019

\title{
Impact of Spatial Extent in the Physical Developments of Urban Residential Growth in Peri-Urban Areas of South-West Region of Nigeria
}

\author{
Owolabi Babatunde Oluwaseyi \\ Department of Urban and Regional Planning, Federal University of Technology, Akure, \\ Ondo State, Nigeria
}

\begin{abstract}
The study identified and examined land uses prevalent in theperi-urban areas of Ikare-Akoko in Ondo state located in the South-West region of Nigeria, evaluated the trend in the examine the socio-economic characteristic of resident in peri-urban area of ikare-Akoko, Identify and examine the features responsible for the growth in peri-urban area in the study area, access resident compliance with development control provisions in the area and assess the human and material resource available to the agencies for development control activities in the study area. This was with a view to providing information that will assist policy makers in effective and efficient planning for future development of the area. Data for this study were both primary and secondary. The primary data was collected through administration of two sets questionnaire. The first set was administered on residents while the second were for staff of town planning authorities in the study area. Identifiable peri-urban areas of Ikare-Akoko are selected. Systematic random sampling technique was used to select (124) houses, respectively. The second questionnaire were administered on the planning authorities in charge of land uses and development in the study area and seek to get information on staff strength and qualifications, number of building plans proposal submitted from 2008-2012 and challenges confronting the agencies in relation to development control in peri-urban areas. The secondary data collected include Goggle Map and GIS imagery of the study area. Data collected was analyzed using descriptive analysis. It was revealed that. $12.8 \%$ of respondents reportedly earned 20,000 naira or less on a monthly basis; $43.1 \%$ of respondents earn between 20,000 and 30,000 on monthly basis; $21 \%$ reportedly earned between 30,000 and 40,000 on monthly basis; $22.9 \%$ of respondents reportedly earned between 40,000 and 60,000 on monthly basis while only $8.2 \%$ earned above $100,000 /$ month. On the average respondents earn $48,500 /$ month. Land use analysis in the study area was determined through an index of 5 and tagged Land Use Index (LUI) revealed that residential land use with LUI of 4.81 was the most important land use in Oba while agricultural (2.10) land use was least. The average land use for Akungba were put (LUI) at 3.5. The LUI for residential was 4.73 and that of commercial was 3.8. A comparative analysis of land uses in revealed that the average rate of land use in Ogbagi was 3.36 while that of Ikare and Okeagbe was 3.58 and 3.51, respectively. It was further revealed that residential land use was ranked first in all the communities under study. The study revealed that the area or land mass Ikare-Akoko were approximately 517.87 acres in 1986 but the settlement has expanded to 1537.69 acres by the year 2012 which indicates or reveals that about 619.82 acres of land or area of vegetation had been converted to residential area over the span of 20-6 years. It was revealed that Ogbagi, Akungba has a greater conversion of her landmass when compared to other areas. The importance of some range of factors in explaining land use conversion in the peri-urban areas of Ikare was determined through, stepwise regression analysis which explains the effects of each factor on the dependent variable. It was revealed that high and middle up positive correlation existed between land use conversion and availability of land $(\mathrm{r}=0.844$ at $\mathrm{p}=0.01)$; rate of population growth $(\mathrm{p}=0.712)$ and government policies $(\mathrm{p}=-0.781 ; 0.01)$. Shortages of manpower were the most constraints facing the operation of these local planning authorities. This particular constraint accounted for $25 \%$ of the total challenges facing the local planning authorities. Next to this was lack of adequate funding having accounted for $22.1 \%$ of the constraints that is being faced by these planning authorities. The study concluded that the rate of conversion of agricultural land use and green space to other land uses particularly residential land use is on the increase in the study area as availability of land, rate of population growth and government policies were established as part of the underline factors for this conversion in the peri-urban areas of Ikare-Akoko.
\end{abstract}

$\underline{\text { Key words: Impact, spatial extent, physical developments, urban residential growth, peri-urban areas, policies }}$

\section{INTRODUCTION}

Background to the study: The issue of population transformation is a major characteristic of cities in the world. This transformation is one from basically rural to urban; though its physical properties differ significantly around the world, the active agent that however cuts across is urbanization (Balchin and Kieve, 2007). 
Urbanization is a process whereby urban population concentrates within a limited space. It also signifies a physical growth of rural land into urban owning to continuous agglomeration of people. According to, one of the factors fueling urbanization is the movement of people from rural to urban areas. When it occurs, the population growth of such urban area is always the same with its migration rate. Urbanization is characterized by physical transformation of the rural or natural landscape into urban land uses owing to massive population migration and stabilization of this population. It is an outcome of social, economic and political developments that lead to urban concentration and growth of large cities, changes in land use and transformation from rural to metropolitan pattern of organization and governance. It is the shift from a rural to an urban society and involves an increase in the number of people in urban areas during a particular year. Indeed, urbanization as a global phenomenon cannot be underestimated.

By half century before 1880 , rural settlements in the United State had a population three times that of the cities. As noted further by 1930 in the United State, the population of rural areas was 54 million and that of the urban was 69 million. Since, 1950, urban population of cities around the world rose from 300 million to 1.3 million. The world population exceeded 5 billion in 1980 increased to 6 billion by 1999 and about 6.8 billion in the year 2011 (Balchin and Kieve, 2007). Cities in countries such as Singapore and Belgium are 100 and 97\% urbanized. This trend is not different in the developing nations.

In Nigeria for instance, urban population was 3.2 million in 1952, 28.32 million in 1991, 67.48 million by 2006 and projected to be 105.19 million by 2015 . Nigeria cities are growing at astonishing pace. The country has one of the largest urban growth rates in the world. The share of the country's urban population increased from $38.0 \%$ in $1993-58.0 \%$ in 2003 while the population grew at an average of $4.2 \%$ per year from $1990-2003$. All these unprecedented increases as opined by Falade (1998) are responsible for the rapid demand for housing and consequently encroachment of certain land uses on the other or adjoining land uses. The conversion of farmlands and watersheds for residential purposes have negative consequences on food security, water supply as well as the health of the people, both in the cities and in the periurban areas. In Nigeria, given the increasing pace of urbanization; the diversification and intensification of other underlying processes; the impact of city expansion is bound to increase in scope and severity particularly in the peripheral areas of the small and medium sized cities such as Ikare-Akoko. Effects of this growth on medium sized cities are noticeable in the attendant problems of traffic congestion, overcrowding, ecological imbalance and environmental degradation. Others are loss of green area, urban sprawl and slum growth. Similarly as the growth is continuous, cities spring up spontaneously and haphazardly without coordinated planning. Despite all these, there is the need to understand in specific context and spatial term, the growth factors in peri-urban and the relationship between these factors and land uses. There is also the need to be abreast of the extent of certain land use development as it expands towards and infiltrates other land uses. This would not only assist in identifying objects of positive policy land use dichotomy but also help in formulating appropriate programs capable of enhancing suitable development and proper utilization of the peri-urban land. It is on this pivot that this study is attempting an examination of the physical planning implication of land use conversion in the peri-urban areas of Ikare Akoko.

Statement of the research problem: One of the major consequences of urbanization in developing countries is the uncontrolled rate of land use and spatial expansion of physical development. It has been predicted that by 2020 , more than half of the world's 8 billion human inhabitants will live in cities and two third of these will be in and around existing urban areas. It is thus expected that the peripheral area (peri-urban interface) would grow rapidly. In essence as the population of the world becomes more urbanized and cities grow, urban planning also becomes more critical; whereas only few people recognize that the management of the environment either the urban or its interface with the rural can only be effective with sound physical planning techniques. Many scholars have attempted a description of the rate of growth of population in urban centre's and how it affects land use (Falade, 1998; Salami, 1997). For example, Adedibu identified two major forces shaping the development of any city in the world: the centripetal and centrifugal forces. The study however gave no attention to forces influencing growth in the peri-urban as well as the influence of residential land use development in the growth of cities.

In another dimension, the work of Falade (1998) reported the rate at which certain development had encroached into other land uses in rural land in Enugu, stating that in 1963, Enugu was $72.52 \mathrm{~km}^{2}$ by 1975 it had doubled to $180.00 \mathrm{~km}$ and by 1985 , it was $204.50 \mathrm{~km}^{2}$. Accordingly, there was an average annual physical expansion rate of $5.98 \mathrm{~km}^{2}$ between 1963 and 1982 in Enugu. Similarly, studied Owerri, the capital city of Imo state and Nigeria and established that there was loss of agricultural land to residential and commercial land uses in the rural area up to a distance of $13 \mathrm{~km}$ to the city. Although, these works dealt with how certain land uses is encroaching into other land uses in the rural particularly agriculture and green space thereby reducing significantly area for cultivation, albeit, the studies was conducted in more than three decades ago, calling for updating. 
Likewise, the choice of Ikare-Akoko is different from the two earlier studied areas. This is important because there is a need for city specific physical planning strategy which emanates from and on the basis of diversity and enormity of problem and structure. Furthermore in their study established that the Visible impact of land use conversion in rural land include surreptitious encroachment on fertile agricultural land and stress on the natural environment with ominous implications for the economic base, socio-economic and demographic characteristics, health and wellbeing of communities in the peri-urban areas. The study also examined the pattern and rate of conversion between rural land uses, submitting that factors such as socio-economic and political development, establishment of institutions and construction of highway were responsible for the growth. In this study and other no consideration was given to examining the physical planning implication of such growth in theperi-urban, most especially in the area of infrastructural provision such as electricity, water supply, road among others. Concerns on this have thus triggered this research work.

In view of the above, this study is set to provide answers to the following pertinent questions. What is the trend of residential development in the study area? What are the factors responsible for land use conversion on the peri-urban lands and what is the direction of growth in the study area? What is the socio-economic background of resident and or residential building developer in the study area? What are the factor influencing the expansion of the centre's? What is the contribution of town planning authority in the study area? Providing answers to these questions would assist in revealing the physical planning implication of land use conversion in the peri-urban area of Ikare Akoko.

\section{The research questions:}

- The research questions of the study are as stated below:

- What are the soci-economic characteristic of resident in peri-urban area of Ikare Akoko

- What are the features responsible for the growth in peri-urban area in the study area

- What are resident compliance with development control provision and

- What are the human and material resource available to the agencies for development control activities in the study area

\section{Aim and objectives}

Aim: This study aims at assessing the spatial extent in the physical development of urban residential growth in peri-urban area land of Ikare-Akoko region with a view to providing information that will assist policy makers in effective and efficient planning for future development of the area.

\section{Objectives}

The specific objectives of the study are to:

- Examine the soci-economic characteristic of resident in peri-urban area of Ikare Akoko

- Identify and examine the features responsible for the growth in peri-urban area in the study area

- Access resident compliance with development control provision

- Assess the human and material resource available to the agencies for development control activities in the study area

Justification of the study: It is obvious that the pattern of land use development in most cities of the developing nations is uncoordinated. The continuous influx of people from the rural to urban areas has resulted into increase in the demand and use of space. Most of these urban activities as noted by are presently been accommodated in the surrounding urban fringe. Because of this, the rural areas have widely become the place where spillover of urban residents, construction and physical development are accommodated. These have provide avenue to land speculators and developers to take unduly interest in urban fringe coupled with this is the native and customary land holding is the peri-urban area. In essence, conflicts are heightened by the increasing economic value of land for development in the per-urban. The state of physical environment development particularly on the urban fringe today is a major source of global concern. The concern is greater in respect of developing nations like Nigeria where physical development growth in the urban areas have been incurring into the neighboring rural areas.

It is no longer arguable that core areas of cities are overcrowded while the peri-urban areas are at the receiving end resulting into uncontrolled and unplanned physical development. These types of development are capable of impacting negatively on the environment by affecting the eco-system and the people, generally. In this sense, controlling the rate of physical development expansion on the fringe of our urban settlements is crucial to the health of the city generally. The peri-urban population is a mixture of rural and urban dwellers. While the rural component of the population are denied the ecological services of unpolluted air, fertile land for farming and are divested of ownership of landed property, the urban component lacks access to basic urban services. In any case, the peri-urban communities is dominated by low income earners that rely on resources from the rural area and cities in constructing their livelihood and sustenance, two composite variables which are indicators of the consequences of urban encroachment into the immediate peri-urban communities whose land uses are being perforated by different forms of urban development. Though, land use changes are indirect consequence of national economic growth, it is important to evaluate land 
use changes in the regional and the local context in order to assist in anticipating the impacts associated with change and contribute to an understanding of productive environmental sustainability. It is not only necessary to understand the changed process in cities, the understanding of the agent of change of beneficiary of change can be useful indicators in planning and declaration of objective functions in cities.

To unravel the present chaotic physical environment condition that has enmeshed policy makers, citizens and professional, especially, town planners in a rather difficult puzzle, there is need to examine the various effects of the uncontrolled developments on the peripherals. This is expected to help in solving physical environmental problems thereby creating functionally and structurally balanced environment suitable for living, working and recreating which is the onus of town and regional planning.

The study area: Ikare-Akoko the study area for this research is the capital city of Ondo state in South West region of Nigeria. It is located on $7.70 \mathrm{~N}$ and long $4.50 \mathrm{E}$ of Greenwich Meridian with an average height of about 300 meters above the sea level. It was founded in the late 18 th century and originated as a traditional as well as cultural town which derives its name from the proclamation by the goddess. The town is known for very rich arts and cultural heritage. Following the creation of Dowall and Clark (1991). It has one local govt. which is Ikare. Its population based on 1991 census was 189,733 and the total land area is about $2,875 \mathrm{~km}^{2}$ before it became the state capital (Falade, 1998; Oyesiku, 1995).

Over the years Ikare-Akoko has witnessed tremendous growth both spatially and in population. The establishment of a railway station is perhaps a major factor in the growth of Ikare-Akoko. Apart from the postal and telecommunication, NEPA regional station, road network, agglomeration of heavy and many light industries, being the seat of government and the presence a good number of higher institutions Ikare-Akoko thus became a major trading and distribution center for people within and outside its immediate environment. In recent times, the location of Ikare-Akoko as a town coupled with other factors mentioned above has led to the influx of people from other villages and towns thus giving it the status of a twin city that is, a traditional as well as a modern city this account for the uncoordinated expansion of the city which has posed serious consequences on land use planning and management. Below are maps showing the study area.

\section{Definition of terms}

Urban area (city): Different people have variously looked at an urban area or centre in different ways, depending upon circumstances such as time, professional orientation and geographical environment. Hence, there is no universally acceptable definition of a city or urban area. The United Nations defined urban area from the demographic point of view as a settlement with more than 20,000 inhabitants living close together. This does not mean that each country does not have its own definition of an urban area. Balchin and Kieve (2007) defined a city or an urban area as a unit of social behaviours. It is also an aggregate of smaller homogenous area, all focusing on the central business district. Simmon defined an urban area as a composite of cells, neighborhoods or communities where people work together for the common goal. He defined further that urban centre's are those localities where there is opportunity for a diversified living environment and diverse lifestyles. In summary, a city or urban area has been seen as synonymous with a compact settlement having a dense concentration of population and performing certain specialized non primary functions, characterized by a predominance of commercial activities and having some degree of control over its surrounding smaller sized settlements. From all these definitions, one can clearly see that some of them lack time and cultural dimension, hence, they are not wholly satisfying and it is not all embracing, so, there is no universally acceptable definition of an urban area or city.

Rural area: A rural area can be described as those relatively small settlements characterized by the predominance of primary activities (agriculture, lumbering, mining among others) as their sole economic base. These areas are subjected to some degree of political, social and economic domination by the city (Bankole). Simmon defined rural areas as any geographical sector that is predominantly made up of villages, dispersed homesteads and agricultural communities. Ogunwale and Toyobo described rural area as an area with a large percentage of agriculture-based occupation that is characterized by relatively homogenous population and free flow of traffic with roads made of earth. Gilg, also defined rural areas as any country with extensive land uses such as agriculture and forestry containing spatially distinctive settlements units with non-urban environment.

Urban fringe: Urban fringe has been perceived as future urban expansion zones through compulsory land acquisition by government. According to them, it can be regarded as sub-urban towns. Fringe area is the interface between the developed and the undeveloped. It is the urban shadow on the metropolitan fringe. Coleman (1976) and Rusuwurun (2004) have defined urban fringe as zones of discontinuity between the city and country. The zone 
possesses characteristics like fragmentation, family land dispute, litigation, speculation and inflation of land prices. There is also presence of pollution, reduction in soil productivity, erosion inadequate basic infrastructure, migration, unemployment and underemployment, poor sanitation and inadequate housing. People that are faced with challenges of high rent relocate in this zone.

A typical example of fringe zone is found in Owerri where the city expands along the major corridors and enveloped the towns and villages. The zone between the city and villages has been converted to urban uses; so as urban growth increases, the urban fringe blends with urban shadow. The fringe zone is known by haphazard and unplanned development of land uses intruding into rural villages. This area accommodates all unapproved land use by planning authority such as junkyards, mechanic villages and waste disposal dump. Hence, there is disorderliness and it lacks aesthetic value. Urban fringe is an area where rural and urban characteristics are mixed together. It is notable for the presence of separate rural and urban groups each with distinctive occupation and attitudes. Some communication networks and railways are located in the urban fringe but now have been swallowed up by urban networks and railways are located in the urban fringe but now have been swallowed up by urban growth. Services like sewage works, service reservoirs, pumping stations that demand more space are located in the fringe but very close to urban. These fringes are at cutting edge of development and often lack the political organization and planning tools needed to cope with an urban invasion. Fringe area often presents a devastated landscape; hence, the development has made agriculture to diminish on a continuous base.

Literature review: The perceived link between the city and the countryside is evolving rapidly, shifting away from the assumptions of mainstream paradigms to new conceptual landscapes where rural-urban links are being redefined. In this conceptual field, the peri-urban interface is still, generally, considered as a transitional zone between city and countryside, often described "not as a discrete area but rather as a diffuse territory identified by combinations of features and phenomena, generated largely by activities within the urban zone proper". These areas are always difficult to define and, moreover, they are also bound with problems inherent to the conceptualization of both rural and urban worlds. In that context, policies aiming to alleviate poverty are still considering the existence of either "rural" or "urban" poverty while the reality of many regions in the developing world suggests that every-day life and livelihood strategies of "multispatial households" are increasingly taking place within an integrated rural urban space. A sharp distinction between urban and rural settlements generally assumes that the livelihoods or the inhabitants can equally be reduced to two main categories: agriculture based in rural areas and manufacture and services based in the urban centre's. Yet recent research suggests that, even where activities can be described as either urban or rural and are spatially separated, there is always a continued and varied exchange of resources between urban and rural areas. The sectorial interaction consists of rural activities taking place in urban areas (e.g., urban agriculture) or traditionally "urban" activities as manufacturing and services taking place in rural areas or even the peri-urban flows to and from rural industries that are spatially concentrated around urban areas. Indeed, it is increasingly accepted that in many regions of the developing world including its largest countries, the boundaries between urban and rural are getting blurred thus, affecting the very definition of such an entity as a peri-urban (or rural-urban) interface. Even if the focus has shifted from a spatial definition (assuming a central urban point surrounded by a de-demystifying periphery) to a more functional focus on diverse flows between the rural and urban sectors, recent developments both in theory and in real world contexts. Such as space-time compression and globalization point to the need of a reassessment of the changing nature of the rural-urban divide, as Douglass puts it: while policy initiatives toward rural-urban linkages have remained attached to the simple urban diffusion and industrial growth pole models, the basic parameters of rural-urban relations and by extension, the prospects for poverty alleviation have been fundamentally transformed by new forms of economic organization, technological change and globalization. Whereas the historical reasons are very different, processes of urban dispersal into rural areas have also been taking place in industrialized economies, being described within a particular segment of the geographic literature for many decades, basically as a result of the counter urbanization dynamics that is the reverse migration from the city to the countryside. Some of the concepts originally coined to describe the rural-urban interface in North America or in Europe, as the peri-urban concept itself or the more widely used in English literature urban fringe are still in use in the Third World analyses (for a complete discussion of the various terms see whereas in the former areas the debate has shifted to the edge-cities or commodities and information leave the central urban context for a restless and place-less periphery.

On the other hand, other scholars argue that while many regions in Asia have witnessed the emergence of functionally integrated territorial structures where 
agricultural and non-agricultural activities are increasingly found in complex spatial mixes, evidence from other regions in the Third World (mainly in Africa where the origin of the peri-urban concept in development contexts can be found in French literature) may suggest that in physical terms the distinction between rural and urban landscapes is still relevant. Nevertheless in functional terms, the increasing and sustained integration is recognized.

Whereas spatial differences can still be noticeable or in a process of blurring, it is generally accepted that while the globalization processes tend to "de-emphasize" place, its effects are most apparent in the largest mega-urban regions of the world. One of the environmental and social challenges of the next century will thus be the rapid and sustained increase of population expected in the fringe of these extended metropolitan regions of the developing world where the city is expanding and industrial activity is being relocated. A "paradigm shift" seems ready to emerge, following a movement initiated in the late eighties by the research about interactions and linkages between rural and urban areas. This trend was seen at that time as a response to "the bulk of research [that] has been devoted to the analysis of urban and rural 'development' as separate issues" expressing a "growing awareness of the importance of urban-rural relationships and dissatisfaction with urban-based centralized models of development".

Factors responsible for urban growth incursion into rural lands: Urban growth is described as the rate at which an urban area increases and expands in size, strength, technology and population. Generally increase in population of urban area is the basis of urban growth. Urban development is increasing rapidly and this is the most significant factor contributing to loss of habitat and endangered species. Some specialists have expressed considerable concern about loss of agricultural land to urban development while others complain that planning controls restrict the supply of land for new developments.

Several factors have accounted for urban growth incursion into the peri-urban lands. According to Turner and human actions rather than natural forces are the source of most contemporary changes in the state and flows of the biosphere. Best and Champion (1970) stressed in his work that there is a correlation between population changes and urban growth pattern. Oyesiku (1995) remarked that growth depends on the natural increase on the part of the total population that is already in urban but it is affected more by the difference in the natural increase level between rural and urban areas. According to Adedibu there are two major forces shaping the development of any city in the world. One is centrifugal while the other is centripetal force. The factors that constitute the later force dominate the development of most of the developing world cities while centrifugal force is often associated with cities of the developed world. Oyesiku, (1995) also identified two major factors responsible for urban growth and these are natural increase and rural urban migration. According to Onibokun and adetoju, population increase account in part for the rapid physical expansion of cities in Nigeria. records that urban development is increasing rapidly and this is the most significant factor contributing to urban expansion into rural lands.

Another factor given by Adindu and Ogbonna for urban growth was rural unemployment increased rural poverty, deteriorating living conditions, declining soil fertility and unchecked rural urban migration. All these are responsible for people's movement out of rural land to the urban entre. Salami (1997) in his work identified the following as factors responsible for continuous loss of rural lands in Ibadan region: urbanization and the associated population increase, nature of urban uses, the landscape configuration, location of development scheme, government policy and pattern of route development. identified route development as a major force in reorganizing land use and this has been widely viewed by many scholars as the pivot for economic growth, production and overall progress of any region. From the above we can generate or summarize the major factors responsible for urban incursion into rural lands: as population increase (i.e., from natural increase or rural urban migration), urban development and pattern of route development.

\section{Rate of urban growth incursion into peripheral lands:} The rate at which urban is encroaching into rural land is highly tremendous, though there is very considerable differences on how urban grows between different regions (Salami 1997). In developed countries, records from different researchers show that rapid urbanization in some of the great cities had displaced rural lands. For example, Best and Champion (1970) study in Britain reveals that about 5,700 acres of agricultural land are transferred to urban uses each year. Bernstein (1994) has shown in different countries how urban developments have led to loss of rural lands. In the Zheijiang province of China, vast areas of agricultural land on the fringes of cities were being converted to urban uses. In Jarkarta, an estimated 40,000 ha of rural land is converted to urban use annually. In jabotabeck, urban lands were expected to expand by 17\% during the period 1980-1995. In Egypt, more than $10 \%$ of the nation's productive farmlands have been converted to urban use during the last 30 years. 
Environ. Res. J., 13 (1-4): 1-20, 2019

Table 1: Annual agricultural land conversion in selected cities

\begin{tabular}{llcl}
\hline Countries & City & Hectares & Period \\
\hline India & Ahmada bad & 5.650 & 1980 \\
India & Bangalore & 1.311 & $1983-2001$ \\
Pakistan & Karachi & 2.400 & $1971-1985$ \\
Colombia & Bogota & 2.325 & 1981 \\
Mexico & Mexico & 4.826 & 1970 \\
\hline
\end{tabular}

Dowall and Clark (1991)

Chabra also established that loss of agricultural land to human settlement is far more serious in India than, elsewhere. He expressed that about 1.5 million ha of land mostly agricultural went to urban growth between 1955 and1985 and further 80,000 ha were expected to be transformed between 1985 and 2000. A vivid example of the rate at which urban land is encroaching into agricultural land is recorded in Sharupur city in India where Fazal, (2000) conducted a detailed study in his study, he came out with the findings.

There has been rapid conversion of agricultural areas to non-agricultural uses. Urban expansion of the city (both built up and non-built up) has destroyed fertile agricultural land which cannot be recovered and the study area is fertile agricultural land which cannot be recovered and the study area is losing agrarian characteristics. Canals and their tributes which used to flow through agricultural fields are now encroached upon and are used for the disposal of garbage and waste.

The study area has lost some 1.685 ha of fertile agricultural land between 1988 and 1998 of which 1.091 ha are recoverable (land where no permanent construction has taken place) and 52 ha are not recoverable land in rural area (land where permanent construction has been undertaken e.g., industry). Table 1 shows annual agricultural conversion in some selected cities in the world.

In Nigeria, Onibokun and Adetoju gave an example of the rate at which urban development has encroached into rural land in Enugu. 1963, Enugu was $72.52 \mathrm{~km}^{2}$ but by 1975 it had than doubled to $180 \mathrm{~km}$ and by 1985 ; it had more than tripled to $204.5 \mathrm{~km}^{2}$. According to them, there was an average annual physical expansion rate of $5.98 \mathrm{~km}^{2}$ between 1963 and 1983. The study conducted by Owerri, the capital city of Imo state shows that there was loss of Agricultural land up to a distance of $13 \mathrm{~km}$ from the city. They establish further that between 1975 and 1985 , proximity to the city resulted in loss of significant hectares of land. Salami (1997) reveals the lateral expansion of the city of Ibadan in all directions. He added that between 1977 and 1990, Ibadan expanded for about $4 \mathrm{~km}$ to the north, $8 \mathrm{~km}$ to the east $4 \mathrm{~km}$ to the south and $3 \mathrm{~km}$ to the West. Similarly, indicated in his study on Akungba that the direction of growth is towards the northern part where Adekunle Ajasin University is located. This is because about $69.5 \%$ building plans were approved in the north compared with $31.5 \%$ in the south.

The research of Adedibu revealed that in 1935 the built up area of Ilorin was $2.0,4.5 \mathrm{~km}^{2}$ in 1963 and 22.3 $\mathrm{km}^{2}$ in 1973. This shows that the city has growth at an astronomical rate and expansion has claimed rural lands.

Physical implications of urban growth expansion into peripherals lands its effects: The implications growth expansion into rural lands poses a serious threat to agricultural land. Nigeria urban center's over the last decade have expanded beyond their limits resulting in the decline of rural area established further that encroachment of urban settlement into rural population. Dowall and Clark (1991) also contended that loss of productive farmland has become a problem in terms of food security. This threat on agricultural land and settlement area is potent. Best and Champion (1970) also supported that in Britain; half of their food was imported because of reduction in farmland. Ruth, suggested that increase demand for food would probably continue to be exceeded by increase physical yield of farm produce when there is likely reduction in farmland. Culling worth noted that much attention has been placed on loss of agricultural land to urban but on the other land, the fact remains that loss of forestry to urban is greater. The resultant effects of urban growth on rural land as highlighted by FAO are accelerated erosion, depletion of productive capacity and alteration of climate and hydrological cycle. Ruth pointed out that it is an unfortunate that the best agricultural land is frequently also the best building land. This is also recorded by Smith and Montgomery that the Eastern part of Ibadan has the best soils and loss of agricultural lands has been recorded to be the highest in this part. It was further stressed that the implication of this is that most fertile area those that are speedily encroached upon. Another effect as mentioned by Adedibu is haphazard development. This is as a result of many unauthorized residential, commercial and industrial development found within and at the periphery of most cities. These developments lack adequate spatial pattern and optimum development thereby causing many problems of economic, social and spatial nature that can retard orderly development. Oyesiku (1995) also pointed out that urban growth result to high intensive use of land and loss of green areas.

\section{Theoretical framework}

Urban growth theories/models: The theories of urban land use have been subjected to number of criticisms amplification and modification, since, the 1920 s. It is a 
(a)

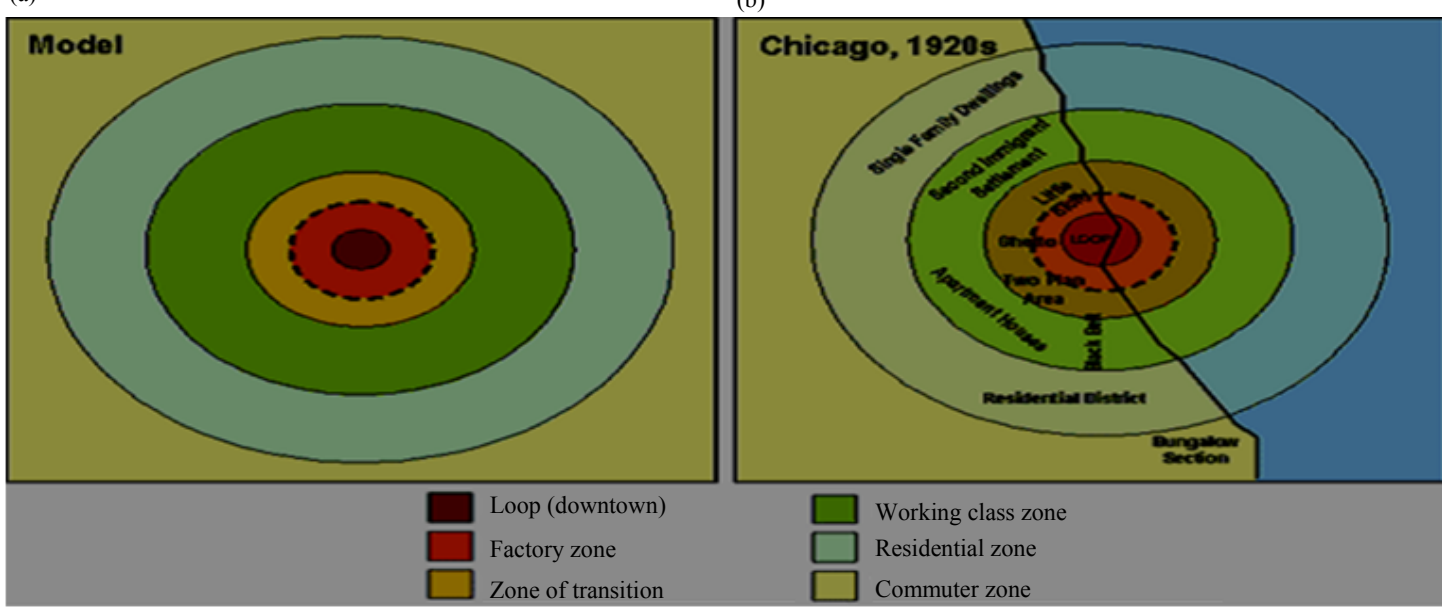

Fig. 1(a-b): Concentric rings

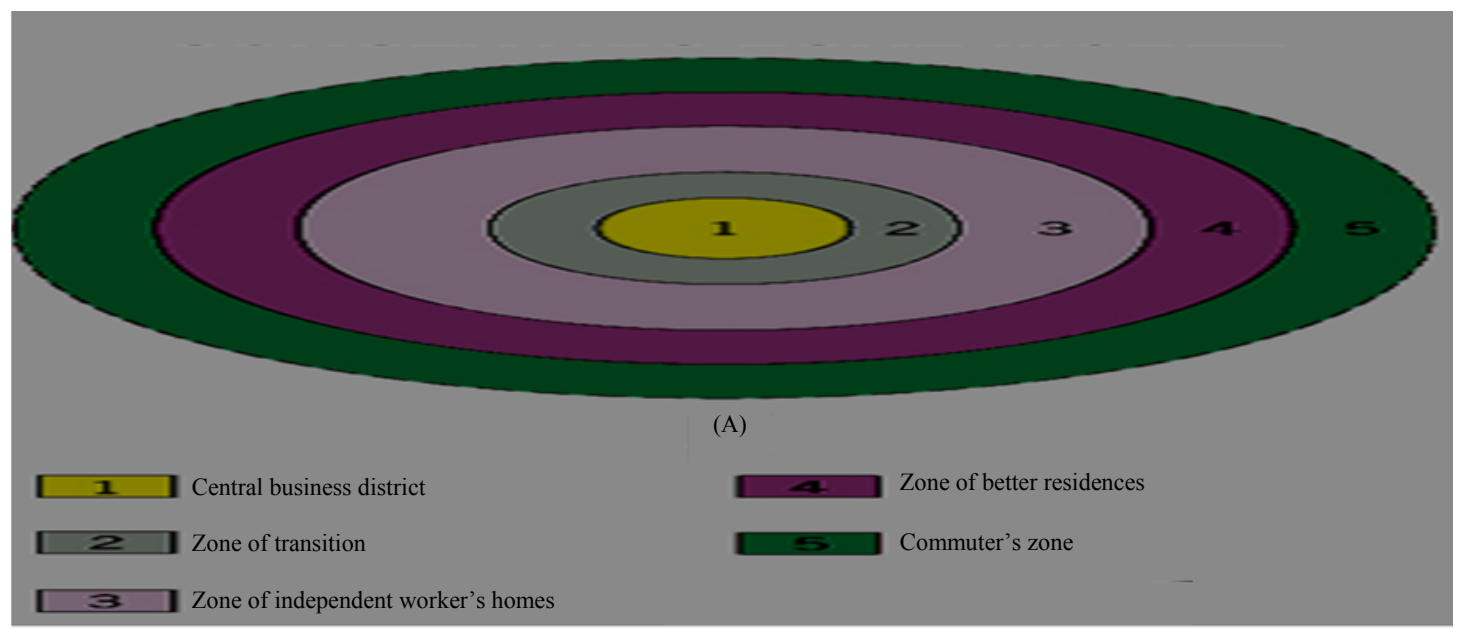

Fig. 2: Concentric zone model

crude attempt to compartmentalize urban systems into structure that we can easily understand and explain. Though the proponents and many authors that had worked on these theories recognized the fact that every city has unique experience and history and thus it is difficult to box into a unified theory or concept the changed process and pattern of any urban area. It is however undeniable that theorizing and modeling urban land use greatly help in simplifying complex urban systems for easy understanding interpretation, comprehension and therefore management. The three best known of urban land use structure theories are the concentric zone theory, the sector theory and the multi nuclei theory.

Concentric zones model: Burgess (1924) developed the concentric zone theory which states that citiestend to expand radially from the centre to form a series of concentric zones. As cities evolved, they displayed increasing complexity over time. The Concentric zone Model resulted from a study of Chicago in the 1920 s by Ernest Burgess. EW Burgess developed the concentric zone theory of urban land use in the mid-1920s based on an examination of the historical development of Chicago through the $1890 \mathrm{~s}$. This model was drawn up at a time when the full impact of the industrial revolution came to bear on the American city (Fig. 1).

The model proposed that the expansion comes about as a result of centripetal forces from an original core and as the growth occurs, each inner zone tends to extend its area by invading the next outer zone following a sequence know as invasion-succession. In other words, the concentric zone theory of urban land use is based on the assumption that a city grows by expanding outwards from a central area, radially in concentric rings of development. The rate of this process depends on the rate of the city's economic growth and on population expansion (Fig. 2). 
Environ. Res. J., 13 (1-4): 1-20, 2019

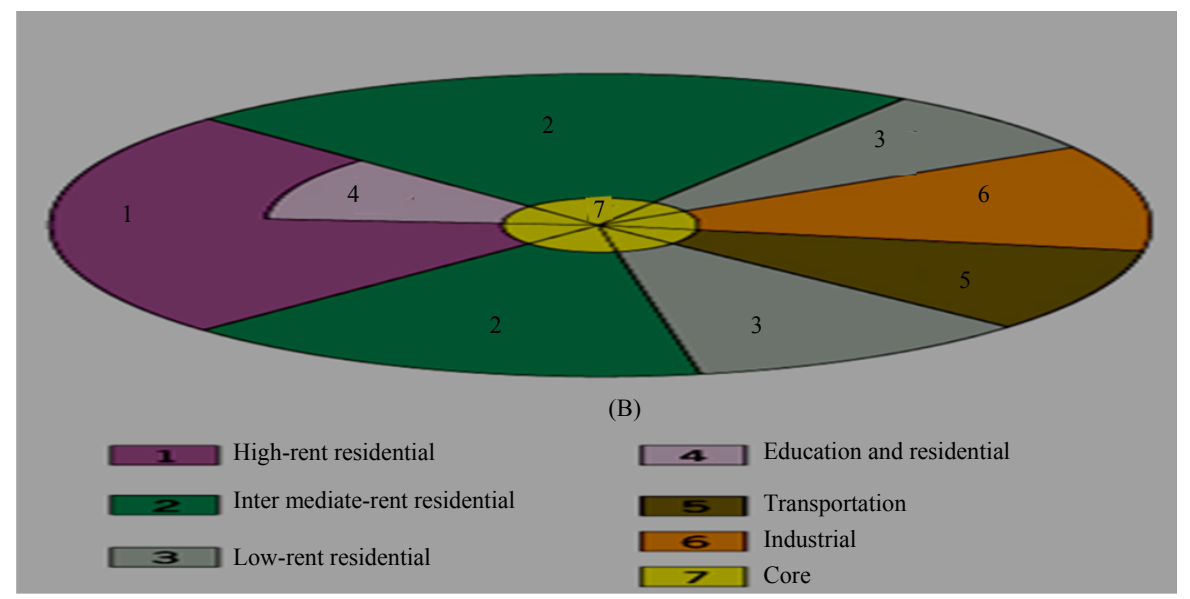

Fig. 3: Sector model

In his study, of American cities, Burgess postulates that urban land use development and pattern are represented in 5 concentric zones and a sixth lying beyond the immediate confine of the urban area.

The Central Business District (CBD) which is the focus of commercial social, civil life and of transportation. The fringe of the $\mathrm{CBD}$ which is an area of wholesale, truck and rail road depot. The zone of transition characterized by property in poor condition and run-down area being invaded by business and light manufacturing. A worke'r housing and factory zone with residence and plants in close proximity. A high class residential zone. A commuter zone of residential suburbs and satellites commercial and shopping areas within accessible time distance.

Though, this theory was based on certain assumptions such as; cultural and social homogeneity, economy based on commerce and industry, private ownership of property and economic competition for space, easy rapid and cheap transportation in every direction the city centre is the main centre for employment. It provides a simplistic view and serves pedagogical purposes with regards to dynamics or urban growth. While useful in a descriptive sense for explaining the location of land uses in a mono-centric city, the work of Burgess has not surprisingly, come under heavy criticism. Amongst the complaints leveled have been accusations that the models are too rigid to ever accurately represent actual land patterns (the mono-centric city assumption is perhaps the largest flaw). They have also been accused of overlooking the important influence of topography and transport systems on urban spatial structure and have been criticized for failing to accommodate the notion of special accessibility and ignoring the dynamic nature of the urban land use pattern (Harri and Ullman, 1945). Hoyt (1939) when he developed the sector theory amplified the limitation of these theories.
Sector theory: Hoyt (1939) developed Radial sector theory, he concentrated on aerial pattern of shifts in residential location. Development of the wedge or radial sector theory of urban land use is generally attributed to the work of Hoyt (1939). Hoyt's Model concerns itself primarily with the location of residential uses across urban areas; it refers to business location only in an indirect fashion. The model seeks to explain the tendency for various socio-economic groups to segregate in terms of their residential location decisions. In appearance, Hoyt's Model owes a great deal to Burgess's concentric zone Model. Hoyt presents wedge-like sectors of dominant urban land use within which he identifies concentric zones of differential rent. The model suggests that, over time, high quality housing tends to expand outward from an urban centre along the fastest travel routes. In this way, Hoyt transforms Burgess's concentric zones into radial or sectorial wedges of land use. $\mathrm{He}$ argued that the different income groups or classes in a city tend to live in district areas describable in terms of sectors of a circle around a city centre. Hoyt argued that the location and extension of high quality zones tend to proceed along the fastest existing transportation lines and either toward another existing nucleus of building of trading center's or toward the section of the city with open country. The competition for the Centre increases rent thereby making it affordable only to the business outfits and the growth along any particular transport route consists of land use of similar characteristics (Fig. 3).

The innovative element in Hoyt's Model was in considering direction as well as distance, as a factor shaping the spatial distribution of urban activity. Hoyt's Model also goes further than its predecessors in recognizing that the $\mathrm{CBD}$ is not the sole focus of urban activity. One major criticism, however is that the model overlooks the location of employment which itself is the major determinant of residential location (Harris and Ullman, 1945). 
However in the Nigerian context and particularly against the contention that the business outfits always occupy the centre, there are certain factors that often influence the concentration of certain economic class or land uses in a given place. Which include social, economic, ethnic and fear of crime? Mabogunje further contested that Nigerian urban centers are rather multi- centric rather than mono-centric.

\section{MATERIALS AND METHODS}

Multiple-nuclei theory: In the 1940s, Chauncey Harris and Edward Ullman, arguing that neither of the earlier models adequately reflected city structure, proposed the multiple nuclei model. This model was based on the notion the $\mathrm{CBD}$ was losing its dominant position and primacy as the nucleus of the urban area. Several of the urban regions would have their own subsidiary but competing "nuclei." As manufacturing cities became modern cities and modern cities became increasingly complex, these models became less and less accurate.

The research of Harris and Ullmann (1945) in developing a multiple-nuclei theory of urban land use is amongst the most innovative descriptive or analytical urban models. Their model is based on the premise that large cities have a spatial structure that is predominantly cellular. This, they explain is a consequence of citie's tendencies to develop as a myriad of nuclei that serve as the focal point for agglomerative tendencies. Harris and Ullmann propose that around these cellular nuclei, dominant land uses and specialized centers may develop over time. The novelty in multiple-nuclei theory lies in its acknowledgement of several factors that strongly influence the spatial distribution of urban activity: factors such as topography, historical influences and special accessibility. The theory is also innovative in its recognition of the city as polycentric. In this sense, it moves closer to explaining why urban spatial patterns emerge (Fig. 4).

Harris and Ullman (1945) contended that cities often develop around several distinct nuclei rather than one centre of origin. These other center's may be district centre established in an earlier urbanization phase and which persist as center's as city growth fills in the space between them. According to the theory, the emergence of separate nuclei reveals four main factors which include; interdependence of some types of activity that have to be close to each other because of dependence on specialized needs.

The tendency or complimentary activities to agglomerate such as retail shops and office buildings. The locational antagonism between dissimilar activities such as heavy industry and high-class residential development. High rent and high land costs may attract or repel certain kinds of land use.

The number of nuclei and their functions will vary from city to city. Generally, the larger the city, the more nuclei it will contain. The major flaw of this theory is the clarification of the characteristic of the nuclei. This integrates the hierarchical core periphery model to the pattern of urban structures. There are traditional centre's, modern centre's, commercial centers, political/administrative centre's industrial centre's and business centre's. These also have ranges of goods and services from their distinct hubs.

Introduction: Research methodology for the study is two parts: methods of data collection and data analysis.

Data collection: Data for this research will be collected from two main sources; primary and secondary sources.

Primary data: The primary sources of data are those collected through, administration of questionnaires and

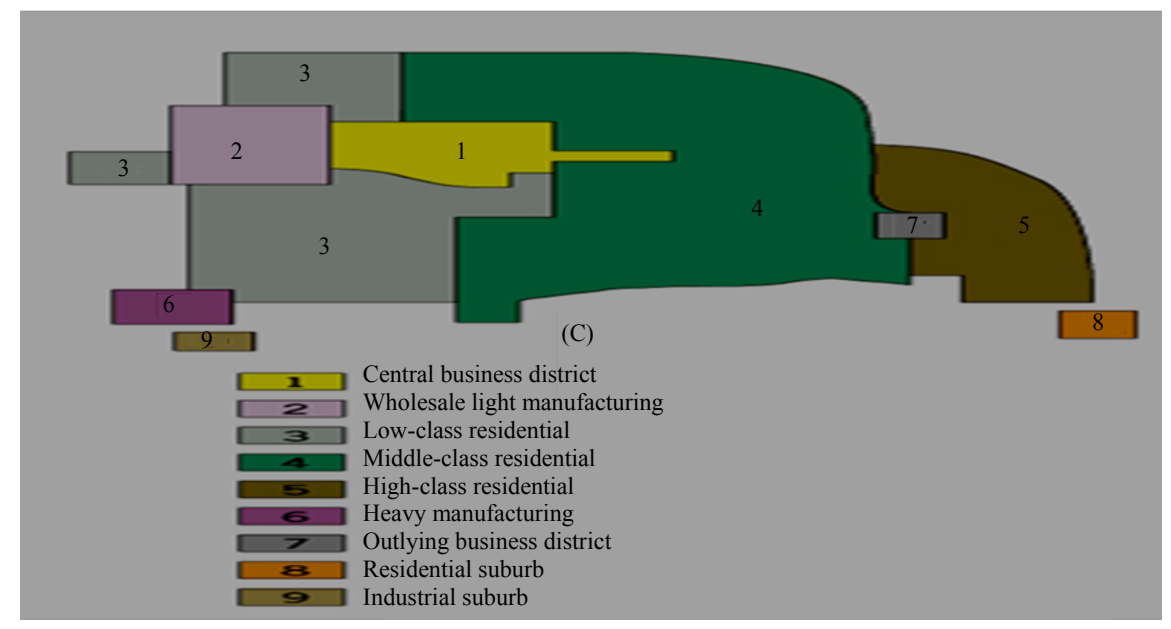

Fig. 4: Multiple nuclei model 
Environ. Res. J., 13 (1-4): 1-20, 2019

Table 2: Identified peri-urban areas in Ikare Akoko

\begin{tabular}{lll}
\hline Major roads & Peri-urban areas & L.G.A. \\
\hline Ikare-Akungba & Okegbe & Akoko-North East \\
Ikare-Iboropa & Ugbe-Akoko & Akoko-South East \\
Ikare-Ogbagi & Okorun & Akoko-North West \\
Ikare-Okeagbe & Ese, Imo, oyin & Akoko-South West \\
\hline Author's Field Survey, 2019 &
\end{tabular}

field observation. The structured questionnaires will be designed to elicit information from the residents of the study area.

Secondary data: In this research, studies that show evidence of learning will be selected as secondary data. These sources of data include relevant books, publications, paper presentations, articles, journals, theses and documented reports.

Selection of houses and house hold for survey: The unit of analysis in this study is the households. Thus, houses where household heads will be selected will be obtained through systematic random sampling technique. This technique involve selecting $k$ (th) case from a population list in a systematic order the sampling interval is the ratio of number of cases in population to the desired sample size. The first ' $\mathrm{k}$ ' will be chosen randomly and subsequent selection of the 50th house along the line of movement. This represents $2.0 \%$ of the buildings.

A household head will be selected in each building of the survey through questionnaire. Information to be sought will include resident's socio-economic and cultural attribute; how these have influenced their compliance to development control activities; development activities embark on for the last 2 years.

Sample frame and size: The sample frame for this study consists of all identifiable peri-urban areas of Ikare-Akoko metropolis. For the purpose of identification, there are five (4) major roads linking Ikare-Akoko with other towns. Along these major roads, there are identifiable peri-urban axes. Reconnaissance survey however revealed that only of these identified peri-urban areas have clear cut boundaries with Ikare Akoko. In selecting areas for survey (Table 2).

Sampling procedure: In the process of selecting samples for survey, the systematic random sampling technique was adopted. Information obtained from the department of town planning and land services, Akungba, Iboropa, Ogbagi and Okeagbe local government councils which forms the sample size, revealed that there were a total number of buildings in the study area. Respondents for questionnaire administration will be selected from one out of every (10) buildings using systematic sampling technique. A household head was surveyed on each floor of the selected buildings. In the absence of a household
Table 3: Numbers of buildings to be surveyed in the selected peri-urban areas

\begin{tabular}{lcc}
\hline Peri-urban areas & $\begin{array}{l}\text { No. of } \\
\text { buildings }\end{array}$ & $\begin{array}{c}\text { Samples to } \\
\text { be surveyed }\end{array}$ \\
\hline Ikare-Akoko-Akungba Akoko & 550 & 55 \\
Ikare-Akoko-Ogbagi Akoko & 320 & 32 \\
Ikare-Akoko-Iboropa Akoko & 150 & 15 \\
Ikare-Akoko-Okeagbe Akoko & 220 & 22 \\
Total & 1240 & 124 \\
\hline
\end{tabular}

Department of Town Planning and Land Services, Akoko-Northeast, Akoko-South West, Akoko-NorthWest, Akoko-Sourth East local government areas

head, available adult was sampled. Using the above sampling procedure, a total of 1,240 and 124 buildings from Akungba, Ogbagi, Okeagbe and Iboropa areas, respectively were selected for survey. Detail of this is as presented in Table 3 .

\section{RESULTS AND DISCUSSION}

This chapter is divided into four sections. The first section identify the soci-economic characteristic of resident in peri-urban area of Ikare akoko while the second section ldentify and examine the features responsible for the growth in peri-urban area in the study area the third section examine the factors influencing land use conversion in the study area and while the fourth and final section assess the planning effects of land use conversion on the physical development in the study area.

\section{Socio economic characteristic of respondents}

Gender of respondent: From the summary Table 4 analysis shows that there is slightly higher number of female respondent than male. About $45 \%$ of respondents are males while $55 \%$ of respondents are female.

Marital status of respondents: From the summary Table 5 analysis also shows that majority of the respondents are married as $96 \%$ of respondents reported so while only $4 \%$ are reportedly single.

Number of years spent in pursuant of formal education: From the summary in the Table 6 respondents were asked to state the number of years they have spent in pursuit of formal education. This question was asked to enable the researcher to determine the level of literacy of respondents. About $27.5 \%$ of respondents reportedly spent only 6 years; $5.5 \%$ spent only 12 years in pursuit of formal education; $11 \%$ of respondents spent just 14 years; $33.9 \%$ spent 16 years; $11 \%$ spent 18 years while $11 \%$ of respondents did not have any formal education. The detail result is depicted below.

Level of education: Presented in Table 7 is to examine the literacy level of respondents, the highest education level of respondents was examined. About 11\% 
Environ. Res. J., 13 (1-4): 1-20, 2019

Table 4: Gender distribution table

\begin{tabular}{lcc}
\hline Gender & Frequency & Percentage \\
\hline Male & 49 & 45.0 \\
Female & 60 & 55.0 \\
Total & 109 & 100.0 \\
\hline
\end{tabular}

Author's field survey of 2019

Table 5: Marital status of respondent table

\begin{tabular}{lcc}
\hline Status & Frequency & Percentage \\
\hline Single & 5 & 4.0 \\
Married & 104 & 96.0 \\
Total & 109 & 100 \\
\hline
\end{tabular}

Author's field survey of 2019

Table 6: Number of years spent in pursuant of formal education table \begin{tabular}{lcc}
\hline Reason & Frequency & Percentage \\
\hline
\end{tabular}

\begin{tabular}{lcc}
\hline 6 & 30 & 27.5
\end{tabular}

$\begin{array}{rrr}6 & 30 & 27.5 \\ 12 & 6 & 5.5\end{array}$

$14-12 \quad 11.0$

$\begin{array}{llr}16 & 37 & 33.9\end{array}$

$18-12 \quad 11.0$

$\begin{array}{lrr}\text { No response } & 12 & 11.0\end{array}$

\begin{tabular}{lrr} 
Total & 109 & 100.0 \\
\hline
\end{tabular}

Author's field survey of 2019

Table 7: Level of education

\begin{tabular}{lcc}
\hline Reason & Frequency & Percentage \\
\hline No education & 12 & 11.0 \\
Primary school & 30 & 27.5 \\
Seniorsecondary school & 6 & 5.5 \\
OND/NCE & 18 & 26.5 \\
HND & 24 & 22.0 \\
B.Sc. & 19 & 17.8 \\
Postgraduate & 2 & 1.8 \\
Total & 109 & 100.0 \\
\hline
\end{tabular}

Author's field survey of 2019

Table 8: Age of respondents

\begin{tabular}{lcc}
\hline Reason & Frequency & Percentage \\
\hline$>30$ & 6 & 5.5 \\
$31-35$ & 18 & 16.5 \\
$36-40$ & 23 & 21.1 \\
$41-45$ & 30 & 27.5 \\
$46-50$ & 18 & 16.5 \\
$>50$ & 14 & 12.8 \\
Total & 109 & 100.0 \\
\hline
\end{tabular}

Author's field work, 2019

reportedly have no formal education; $27.5 \%$ has only primary school education; $5.5 \%$ of respondents have only secondary school education; $26.5 \%$ have either Ordinary National Diploma or Nigeria Certificate in Education; $22 \%$ of respondents have only higher National Diploma; $17 \%$ have bachelor degree while only $1.8 \%$ has postgraduate qualification.

Age of respondents: Presented in Table 8, the mean age of respondents in this study is 43.21 .6 while the median age is 39 years. This indicates that the selection of respondents is evenly distributed across all age groups. About $5.5 \%$ of respondents are 30 years old or less; $16.5 \%$ of respondents are between 31 and 35 years old; $21.1 \%$ are between 36 and 40 years old; $27.5 \%$ are
Table 9: Duration of living in the house

\begin{tabular}{lcc}
\hline Years & Frequency & Percentages \\
\hline$<10$ & 13 & 11.9 \\
$10-15$ & 30 & 27.5 \\
$16-20$ & 12 & 11.0 \\
$21-25$ & 18 & 16.5 \\
$<25$ & 12 & 11.0 \\
Total & 109 & 100.0 \\
\hline
\end{tabular}

Author's fieldwork, 2019

Table 10: Occupation of respondent

\begin{tabular}{lcc}
\hline Reason & Frequency & Percentage \\
\hline Building & 5 & 4.6 \\
Trading & 11 & 10.1 \\
Teaching & 33 & 30.3 \\
Farming & 12 & 11.0 \\
Students & 10 & 9.2 \\
Unemployed & 35 & 32.1 \\
Total & 109 & 100.0 \\
\hline
\end{tabular}

Author's fieldwork, 2019

Table 11: Family size

\begin{tabular}{lcc}
\hline Family size & Frequency & Percentage \\
\hline 2 & 6 & 5.5 \\
3 & 8 & 7.3 \\
4 & 24 & 22.0 \\
5 & 20 & 18.3 \\
6 & 18 & 16.5 \\
7 & 13 & 11.9 \\
8 & 6 & 5.5 \\
$>8$ & 14 & 12.9 \\
Total & 109 & 100.0 \\
\hline
\end{tabular}

Author's fieldwork, 2019

between 41 and 45 years; $16.5 \%$ of respondents are between 46 and 50 years old while $12.8 \%$ are above 50 years.

Duration of living in the house: Presented in Table 9 respondents were asked to state the duration of staying in the house. About $11.9 \%$ of respondents has spent ten years or less; $27.5 \%$ of respondents have spent between 10 and 15 years, $11 \%$ has spent between 16 and 20 years; $16.5 \%$ has spent 21 and 25 years while $11 \%$ of respondents has spent more than 25 years. The average age of duration among respondents is 171.6 years. Thus, it is believed that respondents will be able to provide correct answers to all the questions in this study.

Occupation of respondents: Present in Table 10 it is believed that the occupation of respondents will vary since their levels of education vary widely. About $4.6 \%$ of respondents are builders or construction workers, about 10.15 of respondents engaged trading, businesses; 30.35 of respondents are teachers by profession both in private or government sectors; $11 \%$ are farmers by profession; $9.2 \%$ are still in school, students; $32.1 \%$ of respondents are currently unemployed.

Family size: Presented in Table 11, the number of people in the family and it indicates how small or large a family 
Table 12: Average monthly income

\begin{tabular}{lcc}
\hline Monthly income & Frequency & Percentage \\
\hline 20,000 & 14 & 12.8 \\
$20,000-30,000$ & 47 & 43.1 \\
$30,000-40,000$ & 23 & 21.0 \\
$40,000-60,000$ & 25 & 22.9 \\
$60,000-100,000$ & 9 & 8.2 \\
Total & 109 & 100.0 \\
\hline
\end{tabular}

Author's fieldwork, 2019

Table 13: Types of building

\begin{tabular}{lcc}
\hline Type & Frequency & Percentage \\
\hline Self-contained & 7 & 6.4 \\
Tenement/Brazilian & 37 & 33.9 \\
Traditional courtyard & 42 & 38.5 \\
Duplex & 21 & 19.3 \\
Total & 109 & 100.0 \\
\hline
\end{tabular}

Author's fieldwork, 2019

Table 14: Number of floors in the building

\begin{tabular}{lcc}
\hline No. of floors & Frequency & Percentage \\
\hline 1 & 31 & 28.4 \\
2 & 66 & 60.5 \\
3 & 12 & 11.0 \\
$>3$ & 1 & 0.9 \\
Total & 109 & 100.0 \\
\hline
\end{tabular}

Author's fieldwork, 2019

is. $5.5 \%$ of respondents have 2 members; $7.3 \%$ has 3 members; $22.0 \%$ has 4 members; $18.3 \%$ has 5 members; $16.5 \%$ has 6 members; $11.9 \%$ has 7 members; $5.5 \%$ has 8 members while $12.9 \%$ has more than 8 members. The average family size is 5.7 which are approximately 6 .

Average monthly income: Presented in Table 12, the average monthly income of respondents was assessed to know the financial power of respondents which may invariably measure the extent to which they comply with rules and regulation of building construction. About $12.8 \%$ of respondents reportedly earned 20,000 naira or less on a monthly basis; $43.1 \%$ of respondents earn between 20,000 and 30,000 on monthly basis; $21 \%$ reportedly earned between 30,000 and 40,000 on monthly basis; $22.9 \%$ of respondents reportedly earned between 40,000 and 60,000 on monthly basis while only $8.2 \%$ earned above 100,000 per month. On the average respondents earn 48,500 per month.

Type of building: As indicated in Table 13 respondents were asked to state the type of their building. About $6.4 \%$ of respondents reported that they build a self-contained house, $33.9 \%$ of respondents reportedly built a tenement. Brazilian type of building; $38.5 \%$ of respondents reportedly built a traditional courtyard type; while $19.3 \%$ of respondents built a duplex.

Number of floors in the building: Presented in Table 14 the number of floor in the building was also assessed. Analysis shows that $28.4 \%$ of the buildings have only one floor, $60.5 \%$ of the buildings have 2 floors; $11 \%$ of the buildings have 3 floors and approximately $1 \%$ of the buildings assessed have more than 3 floors.

Cheapcosts of construction materials: Cheap cost of construction materials is another reason mentioned by respondents. Analysis shows that $28.4 \%$ of the respondents strongly agreed that cheap cost of construction materials was the reason for building their house in the location, $32.1 \%$ agreed but $8.3 \%$ of respondents remained undecided while approximately $13.8 \%$ disagreed and $17.4 \%$ strongly disagreed that cheap cost of construction materials was the reason for building the house in that location.

An analysis of variance was carried out to determine factors that that predict the construction of the house in a particular location by respondents. The test was carried out at $95 \%$ confidential interval and 0.05 level of significance. All $p$ values that are $<0.05$ are all significant as opposed to those that are $>0.05$. The result is depicted Table 15.

The result shows that all the reason mention above predicted the building of the house in the location except cost of land and cost of construction materials, since, their p values are $>0.05$ at $95 \%$ confidential interval.

Possession of survey plan: Presented in Table 16, although, it is very essential to possess a survey plan before construction works begin at any building location. About $16.5 \%$ of respondents did not possess any survey plan before they begin construction works on their building. This is against standard practice and the law of the land. The proportion of respondents who reportedly obtain a survey plan is $83.5 \%$ which is fairly high considering the location of the place, semi-urban town.

Reasons for not possessing survey plan: Presented in the Table 17, sequel to the above findings about the percentage of people who reportedly did not obtain survey plan before construction works began on their building, various reasons were given. $5.5 \%$ of respondents complain about the high cost of obtaining the plan from appropriate office; $3.6 \%$ of respondents reported that it is not made compulsory by the planning agencies while $1.8 \%$ of respondents did not see it as necessary. However, no respondents mentioned the delay in construction time as reason for not obtaining the plan before construction.

Preparation of a building plan before construction: Presented in the Table 18, respondents were asked if they prepare a building plan prior building or house development. To this important question, $84.4 \%$ of respondents responded in the affirmative while $15.6 \%$ responded in the negative. Various reasons were given for not preparing a building plan among respondents. The 
Environ. Res. J., 13 (1-4): 1-20, 2019

Table 15: Cheap costs of construction materials

\begin{tabular}{|c|c|c|c|c|c|c|c|}
\hline Reasons & $\mathrm{SA}(5)$ & $\mathrm{A}(4)$ & $\mathrm{N}(3)$ & $\mathrm{D}(2)$ & S.D (1) & SWV & RI \\
\hline To live close to family & 34 & 24 & 12 & 27 & 12 & 368 & 73.6 \\
\hline To have enough space for the development & 34 & 39 & 9 & 17 & 10 & 397 & 79.6 \\
\hline Cheap cost of land & 42 & 35 & 6 & 19 & 7 & 413 & 82.6 \\
\hline Closeness to place of work & 34 & 28 & 9 & 21 & 17 & 368 & 72.4 \\
\hline Town planning regulation is flexible & 42 & 35 & 11 & 18 & 13 & 382 & 76.4 \\
\hline Easy access to other parts of the town & 31 & 27 & 15 & 17 & 19 & 361 & 72.2 \\
\hline Land is free from litigation & 20 & 28 & 17 & 21 & 23 & 328 & 65.6 \\
\hline There is friendly landlord & 18 & 35 & 15 & 27 & 20 & 349 & 69.8 \\
\hline Land and properties are secured & 38 & 39 & 16 & 10 & 6 & 420 & 84 \\
\hline Availability of regular supply of electricity & 31 & 35 & 16 & 15 & 12 & 385 & 77 \\
\hline Regular water supply & 12 & 19 & 11 & 31 & 36 & 67 & 3.4 \\
\hline Availability of good roads & 39 & 38 & 9 & 1 & 12 & 408 & 81.6 \\
\hline Free from floods & 21 & 41 & 8 & 18 & 21 & 350 & 70 \\
\hline \multirow[t]{2}{*}{ Cheap cost of construction material cost of land terrain } & 31 & 35 & 9 & 15 & 19 & 371 & 74.2 \\
\hline & - & - & - & - & - & Ave total & 206.48 \\
\hline
\end{tabular}

Author's field survey of 2019

Table 16: ANOVA

\begin{tabular}{|c|c|c|c|c|c|}
\hline ANOVA & Sum of Squares & $\mathrm{df}$ & Mean square & f-values & Sig. \\
\hline \multicolumn{6}{|c|}{ To live close to family } \\
\hline Between groups & 3.263 & 2 & 1.632 & 6.176 & 0.030 \\
\hline Within groups & 28.003 & 106 & 0.264 & - & - \\
\hline Total & 31.266 & 108 & - & - & - \\
\hline \multicolumn{6}{|c|}{ To live farther away from family } \\
\hline Between groups & 5.140 & 2 & 2.570 & 7.885 & 0.001 \\
\hline Within groups & 34.548 & 106 & 0.326 & - & - \\
\hline Total & 39.688 & 108 & - & - & - \\
\hline \multicolumn{6}{|c|}{ To have enough space of the development } \\
\hline Between groups & 4.677 & 2 & 2.38 & 4.970 & 0.009 \\
\hline Within groups & 49.874 & 106 & 0.471 & - & - \\
\hline Total & 54.550 & 108 & - & - & - \\
\hline \multicolumn{6}{|c|}{ Cheap cost of $L$ and } \\
\hline Between groups & 0.861 & 2 & 0.430 & 7.89 & 457 \\
\hline Within groups & 57.818 & 106 & 0.545 & - & - \\
\hline Total & 58.679 & 108 & - & - & - \\
\hline \multicolumn{6}{|c|}{ Closeness to the place of work } \\
\hline Between groups & 2.625 & 2 & 1.312 & 4.952 & 0.009 \\
\hline Within groups & 28.091 & 106 & 0.265 & - & - \\
\hline Total & 30.716 & 108 & - & - & - \\
\hline \multicolumn{6}{|c|}{ Town planning regulation is flexible here } \\
\hline Between groups & 9.497 & 2 & 4.748 & 15.644 & 0.000 \\
\hline Within groups & 32.173 & 106 & 0.304 & - & - \\
\hline Total & 41.670 & 108 & - & - & - \\
\hline \multicolumn{6}{|c|}{ Easy accessibility to other parts of the town } \\
\hline Between groups & 12.21 & 2 & 6.150 & 18.218 & 0.000 \\
\hline Within groups & 35.69 & 106 & 0.336 & - & - \\
\hline Total & 47.80 & 108 & - & - & - \\
\hline \multicolumn{6}{|c|}{ The land is free from litiigation } \\
\hline Between groups & 10.11 & 2 & 5.060 & 12.029 & 0.000 \\
\hline Within groups & 44.639 & 106 & 0.421 & - & - \\
\hline Total & 54.771 & 108 & - & - & - \\
\hline \multicolumn{6}{|c|}{ There is friendly landlords } \\
\hline Between groups & 13.069 & 2 & 6.540 & 14.793 & 0.000 \\
\hline Within groups & 46.821 & 106 & 0.442 & - & - \\
\hline Total & 59.890 & 108 & - & - & - \\
\hline \multicolumn{6}{|c|}{ Lives and properties are secured } \\
\hline Between groups & 13.352 & 2 & 6.600 & 19.855 & 0.000 \\
\hline Within groups & 35.639 & 106 & 0.336 & - & - \\
\hline Total & 48.991 & 108 & - & - & - \\
\hline \multicolumn{6}{|c|}{ Availability of regular electricity } \\
\hline Between groups & 15.27 & 2 & 7.638 & 10.099 & 0.000 \\
\hline Within groups & 80.173 & 106 & 0.756 & - & - \\
\hline Total & 95.450 & 108 & - & - & - \\
\hline \multicolumn{6}{|c|}{ Regular water supply } \\
\hline Between groups & 22.37 & 2 & 11.178 & 7.345 & 0.001 \\
\hline
\end{tabular}


Environ. Res. J., 13 (1-4): 1-20, 2019

\begin{tabular}{|c|c|c|c|c|c|}
\hline ANOVA & Sum of Squares & $\mathrm{df}$ & Mean square & f-values & Sig. \\
\hline Within groups & 161.331 & 106 & 1.522 & - & - \\
\hline Total & 183.688 & 108 & - & - & - \\
\hline \multicolumn{6}{|c|}{ Availability/good roads } \\
\hline Between groups & 34.72 & 2 & 17.366 & 10.687 & 0.000 \\
\hline Within groups & 172.240 & 106 & 1.625 & - & - \\
\hline Total & 206.972 & 108 & - & - & - \\
\hline \multicolumn{6}{|l|}{ Free froms floods } \\
\hline Between groups & 22.922 & 2 & 11.461 & 9.286 & 0.000 \\
\hline Within groups & 130.821 & 106 & 1.234 & - & - \\
\hline Total & 153.743 & 108 & - & - & - \\
\hline \multicolumn{6}{|c|}{ Cost of construction is fair } \\
\hline Between groups & 0.371 & 2 & 0.185 & .508 & 0.603 \\
\hline Within groups & 38.657 & 106 & 0.365 & - & - \\
\hline Total & 39.028 & 108 & - & - & - \\
\hline
\end{tabular}

Table 17: Possession of survey plan

\begin{tabular}{lcc}
\hline Reasons & Frequency & Percentage \\
\hline Yes & 91 & 83.5 \\
No & 16 & 16.5 \\
Total & 109 & 10.0 \\
\hline
\end{tabular}

Table 18: Reason for not possessing survey plan

\begin{tabular}{lcc}
\hline Reasons & Frequency & Percentage \\
\hline High cost & 6 & 5.5 \\
It is not made compulsory by planning & 4 & 3.6 \\
agency in the area & & \\
It will cause delay in construction time & 0 & 0.0 \\
I do not see it as necessary & 2 & 1.8 \\
Total & 16 & 100.0 \\
\hline
\end{tabular}

Table 19: Did you prepare a building plan before construction commenced

\begin{tabular}{|c|c|c|}
\hline Reasons & Frequency & Percentage \\
\hline Yes & 92 & 84.4 \\
\hline No & 17 & 15.6 \\
\hline Total & 109 & 100.0 \\
\hline
\end{tabular}

$6.4 \%$ of respondents failed to prepare a building plan because it will increase the cost of construction, $2.7 \%$ of respondents reported that obtaining planning approval takes too long and disturbs the construction process; $4.5 \%$ of respondents do not see it as necessary while $1.8 \%$ of respondents reported that they do not trust the planning workers to the extent of doing any business with them.

Did you obtain planning approval before construction commence: Presented in Table 19, Respondents were asked if they obtained a planning approval prior 0 building construction. To this important question, $85.3 \%$ of respondents responded in the affirmative while $14.6 \%$ responded in the negative.

How the planning approval was obtained: Presented in Table 20 when asked how they obtained their planning approval, $5.5 \%$ of respondents reported that they contracted draughtsman or an architect to obtain it for them for a fee; more than a quarter about 25.4 of respondents reportedly contracted it to town planners who helped them to get it at a price. But a large proportion of
Table 20: Reasons for not preparing a building plan before construction

\begin{tabular}{lcc}
\hline Reasons & Frequency & Percentage \\
\hline It will increase cost of construction & 7 & 6.4 \\
Planning approval take too long & 3 & 2.7 \\
I do not see it as necessary & 5 & 4.5 \\
I do not trust planning workers & 2 & 1.8 \\
\hline
\end{tabular}

Table 21: Did you obtain planning approval before construction commence

\begin{tabular}{lcc}
\hline Reason & Frequency & Percentage \\
\hline Yes & 93 & 85.3 \\
No & 16 & 14.7 \\
Total & 109 & 100.0 \\
\hline
\end{tabular}

Table 22: How planning approval was obtained

Reasons Frequency

Contract it to an architect or

\begin{tabular}{cc} 
equency & Percentag \\
\hline 6 & 5.5 \\
& \\
27 & 25.4 \\
54 & 49.5 \\
6 & 5.5 \\
93 & 100.0 \\
\hline
\end{tabular}

draught man

Contract it to town planner

Obtained the approval myself

Bricklayer as middleman

Total

100.0

Author's field survey of 2019

respondents, $49.5 \%$ reportedly obtained it themselves while $5.5 \%$ secure the service of bricklayers to do it for them.

Distance of building to the road: Presented in Table 21, to assess the accessibility of the house to know if the building and construction laws were followed, respondents were asked to state the closeness of their building to the nearest road, $22 \%$ of respondents reported that it is very close, $73.9 \%$ reported that it is close while $4.1 \%$ reported that it is not close. However, the closeness was not determined by measurement.

Distance of building to other house on the right: Presented in Table 22, to assess the spatial distribution of the houses around the building to know if the building and construction laws were followed, respondents were asked to state the closeness of their building to the house on the right side, $38.5 \%$ of respondents reported that it is very close, $50.5 \%$ reported that it is close while $11.0 \%$ reported that it is not close. 
Environ. Res. J., 13 (1-4): 1-20, 2019

Table 23: Distance of building to the road

\begin{tabular}{lcc}
\hline Reasons & Frequency & Percentage \\
\hline Very close & 24 & 22.0 \\
Close & 80 & 73.9 \\
Not close & 5 & 4.1 \\
Total & 109 & 100 \\
\hline
\end{tabular}

Table 24: Distance of building to other house on the right

\begin{tabular}{lcc}
\hline Reasons & Frequency & Percentage \\
\hline Very close & 42 & 38.5 \\
Close & 55 & 50.5 \\
Not close & 12 & 11.0 \\
Total & 109 & 100 \\
\hline
\end{tabular}

Author's filed work, 2019

Distance of the building to other house behind: Presented in Table 23, To assess the spatial distribution of the houses around the building to know if the building and construction laws were followed, respondents were asked to state the closeness of their building to the house behind them, $28.4 \%$ of respondents reported that it is very close, $60.6 \%$ reported that it is close while $11.0 \%$ reported that it is not close.

Percentage of the land developed by respondents: Presented in Table 24 and 25, It was discovered that not all land possessed by respondents were developed completely. Respondents developed different portions of the land. $5.5 \%$ of respondents developed only $35 \%$ of the plot of land that belong to them; $27.5 \%$ developed only $40 \%$ of the plot of land; $11.9 \%$ of respondents developed only $45 \%$ of the plot of land; $11 \%$ developed about half about $50 \%$ of the land; $11 \%$ also developed $55 \%$ of the land; $27.5 \%$ of respondents developed about $60 \%$ while only $5.5 \%$ developed $70 \%$ of the plot of land.

Analysis of Variance (ANOVA) was carried out to determine socio-demographic factors that predict the acquisition of building plan prior to house construction. It was carried out at $95 \%$ confidential interval and 0.05 level of significance. Result of analysis shows that marital status $(p=0.001)$, years of education $(p=0.048)$, level of education $(\mathrm{p}=0.031)$, number of floors $(0.01)$, type of building $(p=0.026)$ and monthly income $(0.023)$ are factors that predict the acquisition of building plan before construction of building. These factors will likely predict others variables such as obtaining survey plan, obtaining planning approval and following planning rules and regulation regarding house construction (Table 26 and 27).

Result of interview of town planners: Five town planning workers were interviewed with structured questionnaire to elicit some information about construction requirement and other construction regulation. Their responses are analyzed and reported as follows:

Requirement for planning permit: Respondent's understanding of the requirement for planning was
Table 25: Distance of the building to other house behind

\begin{tabular}{lcc}
\hline Reasons & Frequency & Percentage \\
\hline Very close & 31 & 28.4 \\
Close & 66 & 60.6 \\
Not close & 12 & 11.0 \\
Total & 109 & 100 \\
\hline
\end{tabular}

Table 26: Percentage of land development by respondents

\begin{tabular}{lcc}
\hline Reasons & Frequency & Percentage \\
\hline 35 & 6 & 5.5 \\
40 & 30 & 27.5 \\
45 & 13 & 11.9 \\
50 & 12 & 11.0 \\
55 & 12 & 11.0 \\
60 & 30 & 27.5 \\
70 & 6 & 5.5 \\
Total & 109 & 100 \\
\hline
\end{tabular}

Author's filed work, 2019

assessed. All (100\%) respondents reported that the following requirement are required, i.e., very important and compulsory: proof of ownership of the land, current special development levy, clearance certificate from relevant local government, original copy of survey plan; photocopy of survey plan, site analysis report, signed by registered town planner, four sets of working drawing, engineering drawing prepared by a registered engineer for the specific project, letter of supervision from by a registered builder or engineer, environmental impact assessment for identified project. But the response concerning there requirement vary. Only $40 \%$ of respondents mentioned the requirement of current income tax clearance certificate, $20 \%$ mention the requirement of tenement rate, $80 \%$ mentioned the requirement of identification of local government of origin. The detail is tabulated below.

Procedures for planning permit: All (100\%) of respondents reported the procedures for obtaining a planning permit before building construction. These include assessment of quality and adequacy of the proposal; opening of file and jacket; payment of registration fees; payment of processing fee; registration of the plan with number; site inspection; recommendation by site officer; application of stamp and seal on the proposal; approval of signature by the approving officer and building plan sign by architect.

Duration of obtaining development proposal approval: About $60 \%$ of respondents reported that it takes between three and four weeks to obtain a development approval while $40 \%$ reported that it takes between 1 and 2 months to obtain it.

Method of communicating agency decision to developer: If the planning is approved, all (100\%) reported that the agency will give a definite time lag within which the applicant will check for decision on the 
Environ. Res. J., 13 (1-4): 1-20, 2019

Table 27: ANOVA

\begin{tabular}{|c|c|c|c|c|c|}
\hline ANOVA & Sum of Squares & $\overline{\mathrm{Df}}$ & Mean square & f-values & Sig. \\
\hline \multicolumn{6}{|l|}{$\overline{\text { Gender }}$} \\
\hline Between groups & 1.345 & 2 & 0.672 & 2.781 & 0.066 \\
\hline Within groups & 25.628 & 106 & 0.242 & - & - \\
\hline Total & 26.972 & 108 & - & - & - \\
\hline \multicolumn{6}{|l|}{ Marital status } \\
\hline Between groups & 5.705 & 2 & 2.853 & 15.035 & 0.000 \\
\hline Within groups & 20.111 & 106 & 0.190 & - & - \\
\hline Total & 25.817 & 108 & & & \\
\hline \multicolumn{6}{|c|}{ How many years on EDU } \\
\hline Between groups & 132.173 & 2 & 66.087 & 3.141 & 0.048 \\
\hline Within groups & 1977.600 & 94 & 21.038 & - & - \\
\hline Total & 2109.773 & 96 & - & - & - \\
\hline \multicolumn{6}{|c|}{ Highest EDU level } \\
\hline Between groups & 4.860 & 2 & 2.430 & 6.974 & 0.031 \\
\hline Within groups & 264.370 & 106 & 2.494 & - & - \\
\hline Total & 269.229 & 108 & - & - & - \\
\hline \multicolumn{6}{|l|}{ How old } \\
\hline Between groups & 631.903 & 2 & 315.951 & 14.483 & 0.080 \\
\hline Within groups & 2312.446 & 106 & 21.816 & - & - \\
\hline Total & 2944.349 & 108 & - & - & - \\
\hline \multicolumn{6}{|l|}{ How long } \\
\hline Between groups & 1605.463 & 2 & 802.731 & 23.959 & 0.078 \\
\hline Within groups & 3551.455 & 106 & 33.504 & - & - \\
\hline Total & 5156.917 & 108 & - & - & - \\
\hline \multicolumn{6}{|l|}{ Family size } \\
\hline Between groups & 26.352 & 2 & 13.176 & 21.699 & 0.000 \\
\hline Within groups & 64.364 & 106 & 0.607 & - & - \\
\hline Total & 90.716 & 108 & - & - & - \\
\hline \multicolumn{6}{|l|}{ Monthly income } \\
\hline Between groups & 2.343E9 & 2 & $1.171 \mathrm{E} 9$ & 18.185 & 0.023 \\
\hline Within groups & $2.963 \mathrm{E} 9$ & 46 & $6.441 \mathrm{E} 7$ & - & - \\
\hline Total & $5.305 \mathrm{E} 9$ & 48 & - & - & - \\
\hline \multicolumn{6}{|l|}{ Type of building } \\
\hline Between groups & 1.619 & 2 & 0.810 & 3.761 & 0.026 \\
\hline Within groups & 22.821 & 106 & 0.215 & - & - \\
\hline Total & 24.440 & 108 & - & - & - \\
\hline \multicolumn{6}{|c|}{ How many stories } \\
\hline Between groups & 5.140 & 2 & 2.570 & 7.885 & 0.001 \\
\hline Within groups & 34.548 & 106 & 0.326 & - & - \\
\hline Total & 39.688 & 108 & - & - & - \\
\hline
\end{tabular}

proposal. If the building plan is not approved, $40 \%$ of respondents reported that the agency will write to the applicant; another $40 \%$ reported that the agency will give a definite time lag within which the applicant will check for decision on the proposal. If the building plan is approved conditionally, $40 \%$ of respondents reported that the agency will write to the applicant; another $40 \%$ reported that the agency will give a definite time lag within which the applicant will check for decision on the proposal.

Steps taken to ensure the builder adhere strictly to building plan: All $(100 \%)$ of respondents reported that the agency staff will be involved in the construction process to enable them monitor the construction. They all also reported that agency will certify a very stage of the project; and embark on regular monitoring; lastly they all reported that adoption of public participation in monitoring of development. All these will help to checkmate deviation from building plan.
Instrument available to control development: Respondents were asked to mention the instruments that are available to control development. All (100\%) mentioned master plan; layout/subdivision plan; environmental impact assessment; plot coverage; setback from the road; state urban and regional planning law; national urban and regional planning law and EIA decree No 86 of 1992 . Also $80 \%$ of respondents mentioned the following height zoning; stop work notice; contravention notice; zoning notice while only $60 \%$ mentioned paint and brush.

The focus of this chapter is on two issues. The first issue discussed is the summary of the major findings of the study and the second section documented recommendations that could be employed in land use management in peri-urban areas of Ikare Akoko. These were respectively, discussed under sections 5.2 and 3.3, respectively.

Summary of findings: The study revealed those medium income groups were largest in proportion having taken 
account of $63.9 \%$ of the total resident's survey in the study area. While, $12.8 \%$ of respondents reportedly earned 20,000 naira or less on a monthly basis; $43.1 \%$ of respondents earn between 20,000 and 30,000 on monthly basis; $21 \%$ reportedly earned between 30,000 and 40,000 on monthly basis; $22.9 \%$ of respondents reportedly earned between 40,000 and 60,000 on monthly basis while only $8.2 \%$ earned above 100,000 per month. On the average respondents earn 48,500 per month It was discussed that residents with no formal education accounted for $8.4 \%$ while those with formal education were $91.6 \%$. It was further revealed that $27.5 \%$ of respondents reportedly spent only 6 years; $5.5 \%$ spent only 12 years in pursuit of formal education; $11 \%$ of respondents spent just 14 years; $33.9 \%$ spent 16 years; $11 \%$ spent 18 years while $11 \%$ of respondents did not have any formal education.

It was revealed that their level of education vary widely. About $4.6 \%$ of respondents are builders or construction workers, about 10.15 of respondents engaged trading i.e., businesses; 30.35 of respondents are teachers by profession both in private or government sectors; $11 \%$ are farmers by profession; $9.2 \%$ are still in school i.e., students; $32.1 \%$ of respondents are currently unemployed. It was revealed that. $6.4 \%$ of respondents reported that they build a self-contained house, $33.9 \%$ of respondents reportedly built a tenement. Brazilian type of building; $38.5 \%$ of respondents reportedly built a traditional courtyard type while $19.3 \%$ of respondents built a duplex. The study further revealed that about $16.5 \%$ of respondents did not possess any survey plan before they begin construction works on their building. This is against standard practice and the law of the land. The proportion of respondents who reportedly obtain a survey plan is $83.5 \%$ which is fairly high considering the location of the place, i.e., semi-urban town. The average household sizes in each of the peri-urban mentioned above. No statically significant exist in the household distribution of the resident as F value computed from ANOVA was 5.306 at $\mathrm{p}=0.086$. The proportion of residents who had resided, respondents have spent. About $11.9 \%$ of respondents have spent 10 years or less; $27.5 \%$ of respondents have spent between 10 and 15 years, $11 \%$ has spent between 16 and 20 years; $16.5 \%$ has spent 21 and 25 years while $11 \%$ of respondents has spent more than 25 years. The average age of duration among respondents is 171.6 years.

Prevalent land use in the study area was determined through an index of 5 and tagged land "Land Use Index" (LUI). Land use index in Ikare-Akoko as perceived by the residents. From the summary, it was evident that two pattern of land use with positive Mean Derivation (MD) index and those with negative Mean Derivation index (MD). Land uses with positive derivation index were important and most frequent land use. These include residential land use, commercial land use and public use as well. The land use indices of these land use were 4.87 ,
$4.02,3.71$ and 3.52 , respectively, for residential, commercial, public land use and circulation. With the average land use index of 3.36 computed for Ikare Akoko, it were established that residential land use with LUI of 4.81 was the most important land use in this area while agricultural land use was least practice having accounted for a mean land use index of 2.01 .

Presented in Table 25 and 26 is the Land Use Index (LUI) of Ikare Akoko. The average land use index in this community were put (LUI) at 3.5. The LUI for residential was 4.73 that of commercial was 3.81 while the index for other forms of land uses in the area not listed in the table was put at 3.67. Those land uses with less importance were attached were public use, circulation, agricultural and institutional land use. The LUI of these were 3.52, $3.43,3.02$ and 2.91, respectively. The least important land use in this area was institutional land use with LUI of 2.91. The average land use index in this community was denoted by $L I_{c}$ and this was computed to be 3.51 ., those land uses with LUI below LUI $_{c}$ were public land use. Circulation institutional and other land uses are not listed as well as agricultural land use. The indices of these land uses were $3.46,3.11,3.01$ and 2.27 , respectively. With an index of 2.27, agricultural land use was rated as the least important with residential land use (LUI $=4.53$ ) was the most important.

A comparative analysis of land uses in those selected communities shows that the average rate of land use in Ogbagi was 3.36 while that of Akungba and Okeagbe was 3.58 and 3.51, respectively. Thus, higher utilization of land was Akungba while Okeabge recoded the least rate of utilization. It was further revealed that residential land use was ranked first in all the communities under study. In similar trend of distribution with residential was commercial land use. This was ranked second in all the communities. That is with LUI of 4.02 , commercial land use was ranked second after residential land use in Ogbagi in Ikare (LUI = 3.81) and in A with LUI= 4.53 .

The study revealed that the area or land mass Ikare-Akoko were approximately 917.87 acres in 1986 but the settlement has expanded to 1537.69 acres by the year 2012 which indicates or reveals that about 619.82 acres of land or area of vegetation had been converted to residential area over the span of twenty-six years. Ogbagi in 1986 shows that the total land mass of the area covered by settlement is 528.20 acres but by the year 2012 it has increased. It was revealed that Okeagbe have a greater conversion of her landmass when compared to other areas.

The importance of some range of factors in explaining land use conversion in the peri-urban areas of Ikare-Akoko. The technique used is the stepwise regression analysis which explains the effects of each factor on the dependent variable. Significant variable were selected based on the F-ratio value. It was revealed that 
high and middle up positive correlation existed between land use conversion and some socio-economic characteristics of the residents of the peri-urban areas of Ikare Akoko. These were gender $(r=0.782, \mathrm{p}<0.01)$, house type $(\mathrm{r}=0.694, \mathrm{p}<0.01)$ and level of education $(\mathrm{r}=0.513, \mathrm{p}<0.01)$. In addition, availability of land was also significant at $\mathrm{r}=0.844$ at $\mathrm{p}=0.01$; rate of population growth at $\mathrm{p}=0.712$ and government policies $(\mathrm{p}=-0.781$; $\mathrm{p}=0.01$ ).

It was reveal that shortages of manpower were the most constraints facing the operation of these local planning authorities. This particular constraint accounted for $25 \%$ of the total challenges facing the local planning authorities. Next to this was lack of adequate funding having accounted for $22.1 \%$ of the constraints that is being faced by these planning authorities.

\section{CONCLUSION}

The study concluded that the rate of conversion of agricultural land use and green space to other land uses particularly residential land use is on the increase in the study area as availability of land, rate of population growth and government policies were established as part of the underline factors for this conversion in the peri-urban areas of Ikare Akoko.

\section{RECOMMENDATIONS}

Base on the findings from this study, development control in peri-urban area is a major physical problem that has being a treat to the environment. The cause of this has been identified in the study and the following are recommended that government, planning authority and developer should be more responsive to development control. Government should revise it obsolete policies and enact planning authority giving priority attention on effective enforcement and sanctioning on development control. Development control should be improved by the following ways:

Planning enlightenment: The solution to the problem of development control in the town still lies largely on the planning institutions. There should be public enlightenment and mass education of the people on the importance and implication of development control. The planning institutions or agencies need to sensitize the public towards the existence of development control.

The existing government promulgated law: The urban and regional planning law, decree 88 of 1992 and the amendment decree no 88 of 1999 has enough and detailed provisions for effective development of urban areas but supreme court judgment does not make it legally straight forward instrument for application. So, it is advisable that state should adopt the urban and regional planning law, decree 88 of 1992 with necessary modifications. Amendment decree No. 18 of this law where the commission, board and authority will effectively monitor urban and regional activities in federal, state and local government, respectively, for the good urban governance to strive well in Ikare-Akoko.

Sufficient fund: This should be made available for urban development and planning agencies at the three level of government. These authorities should not be seen as revenue generating agencies, for self-sustainability. Instead, the state government should provide fund for plan preparation and implementation through the mechanisms of development control. Also, logistics such as vehicles, stationaries and all office equipment should be properly supplied to ensure effective development control exercise. Government should employed more professional qualified town planner in the town planning office, to effectively undertake contravention drives and to ensure steady implementation of plans for development. Allied professional staff such as architect, estate managers, quality surveyor and civil engineers is necessary to compliment the job of town planners whatever development plans that are prepared for the town, effective implementation depends on the quality and caliber of staff of authority.

For areas that have grown beyond management, an urban renewal strategy should be adopted. In the respect, upgrading, conservation andrehabilitation approaches are preferred over the demolition and redevelopment approach because the former is more economically and politically acceptable. It less disruptive of socialites and economics activities and also gives the individual family and opportunity to improve their living environment, as their means improve.

The various agencies responsible for physical development and control should be properly co-ordinated to enhance co-operation to eliminate mistrust, so that, decisions can flow naturally from bottom to top and to reduce and eventually eliminate undue delay in processing and approval of application for planning permission

Planning is government control and development control is public oriented. The level of contravention is a bit high in Ikare. The law should empower the planning officer to prosecute all cases of illegal developments even when the government refuses to co-operate all amendments in plans development without approval from the planning office should be subjected to public scrutiny. The people must convince of the need and justification for such amendments.

Provision of development plans: The planning institution needs to provide the planned environment that will make access available and easy for developers. So, efforts must be intensified on layout planning and 
development. The layout plots must also be made available to all. There is always a threat to development control where layout plot are made available to a few people. Above all, enforcement of development control in a proactive manner that could prevent any need for demolition should be emphasized.

\section{REFERENCES}

Balchin and Kieve, 2007. Urban Land Economics. Macmillan Publishers Ltd., London, UK.,.

Bernstein, J.D., 1994. Land use Considerations in Urban Environmental Management. The World Bank, Washington, D.C., USA., ISBN: 9780821327234, Pages: 99.

Best, R.H. and A.G. Champion, 1970. Regional conversions of agricultural land to urban use in England and Wales, 1945-67. Trans. Inst. Br. Geogr., 49: $15-32$.

Burgess, E.W., 1924. The Growth of the City: An Introduction to a Research Project. Vol. 18, Bobbs-Merrill Company, Indianapolis, Indiana, USA., Pages: 90.

Coleman, A., 1976. Canadian Settlement and Environmental Planning. Vol. 5, The Ministry of State for Urban Affairs, Canada,
Dowall, D.E. and G. Clark, 1991. Making urban land market work: Draft paper preparedfor the urban management programme. World Bank, Washington, D.C., USA.

Falade, J.B., 1998. Public acquisition of land for landscaping and open space management. J. Niger. Inst. Town Planners, 11: 1-13.

Fazal, S., 2000. Urban expansion and loss of agricultural land-a GIS based study of Saharanpur City, India. J. Environ. Urbanization, 12: 133-149.

Harris, C.D. and E.L. Ullman, 1945. The nature of cities. Ann. Am. Acad. Political Soc. Sci., 242: 7-17.

Hoyt, H., 1939. The Structure and Growth of Residential Neighborhoods in American Cities. US Government Printing Office, Washington, D.C., USA., Pages: 180.

Oyesiku, O.O., 1995. Effects of anthropogenic activities on rural urban migration in Africa: The Nigeria case. Proceedings of the 5th International Workshop on Society of African Physicists and Mathematicians, August 8-9, 1995, Ghana, West Africa, pp: 14-18.

Rusuwurun, L.H., 2004. The development of an urban corridor system: Toronto startorm area (1991-2000). Regional Development Branch Report. No 3. US Department of Treasury, UAS.

Salami, A.T., 1997. Urban growth and rural land retreat in Ibadan area of southwestern Nigeria, 1935-1995. IFE. Plann. J., 1: 107-119. 